\title{
A casa como imagem em três poemas de Dragica Rajčić
}

\author{
[The House as Image in Three Poems by Dragica Rajčić] \\ http://dx.doi.org/10.11606/1982-8837234043
}

Dionei Mathias $^{1}$

\begin{abstract}
Published in German, in 2000, the collection of poems Post Bellum written by Dragica Rajčić concerns war memories in the Balkans and the principle of otherness experienced by the lyrical I. This article discusses three poems from this collection: "suisse like home", "Hunderste gedicht ohne trenen" and "Ein Haus, nirgends". Focusing on the representation of home, this article begins with a theoretical discussion on the concept of home and goes on to discuss the poems and their home images, interested, above all, in the matter of belongingness.
\end{abstract}

Keywords: Dragica Rajčić; home; Post Bellum; belongingness.

Resumo: Publicada em alemão no ano de 2000, a coletânea Post Bellum de Dragica Rajčić trata das memórias da guerra nos Bálcãs e do princípio de alteridade experimentado pela voz lírica. Este artigo tem por objetivo discutir três poemas dessa coletânea: "suisse like home", "Hunderste gedicht ohne trenen" e "Ein Haus, nirgends". Com foco na figuração da casa, o artigo inicia com uma discussão teórica do conceito de casa e passa a discutir os poemas e as imagens da casa, com interesse, sobretudo, na questão do pertencimento.

Palavras-chave: Dragica Rajčić; casa; Post Bellum; pertencimento.

\section{Introdução}

Dragica Rajčić, nascida na Croácia, vive e trabalha na Suíça, onde escreve em língua alemã. Com algumas coletâneas de poemas já publicadas e condecorada com prêmios literários importantes, como o Prêmio Adelbert von Chamisso de 1994, Rajčić se afirma como uma importante voz da literatura suíça de expressão alemã na produção contemporânea, ao lado de escritoras como Ilma Rakusa, Aglaja Veteranyi ou Zsuzsana Gahse (MATT 2007: 424). Sua obra não é extensa. Em 1986, ela publicou a coletânea Halbgedichte einer Gastfrau (traduzido livremente como Poemas incompletos de uma imigrante), e seu último texto, Warten auf Broch ("Esperando por Broch”), no qual

\footnotetext{
${ }^{1}$ Universidade Federal de Santa Maria, Departamento de Letras Estrangeiras Modernas, Av. Roraima, 1.000, Camobi, Santa Maria, RS, 97105-900, Brasil. E-mail: dioneimathias@ gmail.com. ORCID: 00000001-8415-1460
}

\section{(cc) BY-NC}

Pandaemonium, São Paulo, v. 23, n. 40, mai.-ago. 2020, p. 43-62 
Mathias, D. - A casa como imagem

dialoga com Hermann Broch, é de 2011. Todos esses textos têm em comum a preocupação e inquietação com a materialidade da língua.

Seu estilo parece oscilar entre uma tessitura imagética marcada pelo hermetismo e uma poética de captura de imagens do cotidiano que desejam revelar uma determinada percepção, sem transformar suas imagens numa superfície opaca. O snapshot como captura instantânea de uma percepção ou sensação remete à técnica adotada e introduzida na literatura de expressão alemã por Rolf Dieter Brinkmann, inspirado, por sua vez, pelas técnicas da poesia americana, como Walter Hinck (2000: 231) esclarece em seu estudo. A utilização desse termo para descrever uma faceta da poesia de Rajčić se dá pela proximidade da técnica de capturar uma imagem instantânea, sob uma pressão de tempo encenada, como é o caso do primeiro poema a ser discutido na sequência. Ao mesmo tempo, a utilização em inglês do termo snapshot, adotado por muitos estudiosos para descrever a poesia de Brinkmann, deseja indicar uma afiliação a uma tradição poética, na qual os poemas a serem estudados se enquadram. Entre hermetismo e snapshot, essa escrita instaura uma voz própria que afirma seu lugar de fala de estrangeira não somente no contexto sociocultural, mas também no modo de utilizar-se da língua como matériaprima para sua arte.

Esse lugar de fala se condensa na coletânea Post Bellum, publicada em 2000. A voz estrangeira presente no eu lírico capta imagens e experiências do pós-guerra nos Bálcãs. No lugar, contudo, de utilizar uma língua estilizada no sentido de imitar o idioleto de falantes nativos, Rajčić utiliza uma voz lírica que não apaga a diferença inerente à condição de estrangeiro. Em sua discussão, Probul (1997: 36) a caracteriza como "idioleto de uma estrangeira" (em alemão: “Idiolekt einer Ausländerin”). Essa estratégia é bastante usual em textos cômicos, nos quais a estrangeiridade serve como material para a produção de comicidade ou para a exposição de movimentos subversivos por parte de grupos minoritários frente às máquinas de silenciamento de grupos dominantes. Nessa coletânea, no entanto, a voz estrangeira é utilizada para armazenar os sedimentos da dor, com todas as suas marcas de diferença. Nisso, o eu lírico reflete sobre a devastação da guerra, mas também sobre o seu lugar no mundo, empreendendo tentativas de construir analogias entre o lugar de partida e o novo destino.

Uma das inquietações claramente marcadas na coletânea é justamente o pertencimento, mais especificamente a configuração espacial da casa como símbolo de arraigamento existencial. No contexto da literatura oriunda de fluxos migratórios, a casa

Pandaemonium, São Paulo, v. 23, n. 40, mai.-ago. 2020, p. 43-62 
Mathias, D. - A casa como imagem

tem um papel especialmente importante, pois revela como indivíduos se posicionam ou são posicionados em novos contextos de interação social. Nisso, o sentir-se em casa assume as mais diversas conotações, desde um espaço demarcado até uma constituição afetiva que define o grau de bem-estar do indivíduo.

Essa complexidade semântica começa com a diferença das conotações atualizadas nas diferentes palavras utilizadas para simbolizar esse elemento da realidade. Com efeito, essa simbolização tem dois eixos: um espacial e outro afetivo, como é possível identificar nos pares casa/lar, Haus/Heim e house/home. O primeiro elemento de cada par remete primeiramente à construção da casa, como espaço físico delimitado. O segundo elemento remete, primordialmente, ao contexto afetivo produzido no espaço da casa ${ }^{2}$. Enquanto as palavras inglesas - importantes neste contexto, pois a autora emprega a palavra "home" como título de um de seus poemas - parecem ser utilizadas com igual frequência no uso coloquial da língua, mantendo a diferença semântica, as palavras "lar" no português e "Heim" em alemão têm uma frequência menor de utilização, em comparação ao uso de "casa" e "Haus". No lugar dessas palavras - que não deixam de ocorrer em determinados contextos - percebe-se o emprego das palavras primordialmente previstas para simbolizar a construção, remetendo também ao contexto afetivo ("ser de casa", por exemplo), ou a utilização de outros termos ou estratégias para recuperar essa ideia (“das Zuhause” em alemão, por exemplo). Esse escopo semântico fica ainda mais complexo de descrever se levadas em consideração as diferenças regionais no uso de cada uma dessas palavras, nas diferentes comunidades linguísticas. Independentemente do uso específico, parece haver um claro anseio de diferenciar esses dois teores semânticos.

A teorização desse conceito começa pela definição da casa como lugar de proteção contra as intempéries, mas também contra os perigos que rondam o espaço mais amplo de circulação do sujeito. Já nesse primeiro passo de definição, a construção da casa como mecanismo que define modalidades do ser no mundo, há uma dimensão afetiva que reside no cerne desse empreendimento. Assim, o desejo de proteção revela um anseio de economizar energias que, de outro modo, seriam investidas em atenção para antecipar possíveis riscos à estabilidade da existência. A casa, portanto, num primeiro momento representa a produção de um espaço simbólico que permite ao indivíduo canalizar suas energias de atenção e percepção para outras finalidades afetivas.

\footnotetext{
${ }^{2}$ A palavra "lar" remete etimologicamente ao lugar onde se acendia o fogo na cozinha, um espaço, portanto, que parece reforçar o bem-estar, o aconchego, isto é, uma atmosfera afetivamente positiva.

Pandaemonium, São Paulo, v. 23, n. 40, mai.-ago. 2020, p. 43-62
} 
Mathias, D. - A casa como imagem

Casa é um espaço de controle e orientação (Douglas 1991: 289). Na vastidão do espaço que forma o entorno do sujeito, as coordenadas limitadas da casa permitem ao indivíduo definir como vai administrar a vida ali. Os potenciais de agência diferem daqueles existentes em outros espaços, embora também aqui os outros membros que compartilham essas coordenadas tenham um impacto sobre regras, rituais e escopo de ação. A despeito das restrições que surgem no convívio de grupos, o potencial de controle é maior que fora dos muros da casa. Ao lado do controle, a casa também funciona como norte de orientação. Após as negociações sociais do dia, com suas inúmeras excursões, o indivíduo orienta seu corpo para retornar ao lugar de pertencimento. Essa orientação pode ser entendida como norte geográfico, mas implica também um horizonte de valores que predomina naquele espaço, fornecendo ao indivíduo um conjunto de interpretações sobre como agir e pensar no mundo, orientando, portanto, também as modalidades de ação.

Nos dois casos, o trabalho de imaginação individual é imprescindível. Douglas (1991: 290) escreve: “O motivo pelo qual algumas casas ${ }^{3}$ [homes] apresentam [ideias] mais complexas e mais delimitadoras que outras depende das ideias que as pessoas têm em suas cabeças sobre suas vidas no espaço e no tempo. Pois a casa [home] é a realização de ideias"4. A afirmação de Mary Douglas parece indicar a importância da narrativa que envolve esse conceito. $\mathrm{O}$ espaço e o tempo nos quais se espraiam as coordenadas da casa não seriam suficientes se não houvesse uma tessitura subjetiva que atribui colorações de sentido e, com isso, dimensões afetivas a esse espaço.

Como bem afirma Bozkurt (2009: 27) ao analisar a ideia da casa no contexto de imigrantes turcos na Alemanha, para ser denominado de "casa" não basta que seja o lugar onde se desfaz a mala após o retorno de uma viagem. $\mathrm{O}$ investimento intelectual e, sobretudo, afetivo na tessitura de uma narrativa que imagina esse espaço se revela como essencial. Essa narrativa, no entanto, não se restringe somente ao plano individual, incluindo também os círculos mais amplos nos quais o espaço pessoal está englobado. Trata-se das narrativas macrossociais às quais o indivíduo se sente afiliado:

Ao mesmo tempo, ansiamos incansavelmente [restlessly] por um lugar de descanso [rest]. A cultura popular oferece pacotes personalizados: genealogias de família; peregrinações aos monumentos de imigração, como Ellis Island; livros sobre tradições étnicas; passeios ao país natal perdido; comunidades de assinantes que compartilham a mesma rede, o

\footnotetext{
${ }^{3}$ A palavra inglesa "home" foi traduzida aqui como casa, no sentido afetivo, discutido anteriormente.

${ }^{4}$ No original: "Why some homes should have more complex orienting and bounding than others depends on the ideas that persons are carrying inside their heads about their lives in space and time. For home is the realization of ideas".
} 
Mathias, D. - A casa como imagem

mesmo papo ou a mesma causa; um compêndio de citações reconfortantes, até mesmo a filosofia do baseball, a qual define o jogo de todos os americanos como um jogo que deseja alcançar a base [reach home] e aprender quão difícil é chegar lá. (LEONTIS 1999: 3$)^{5}$

Nessa dimensão do conceito de casa, o espaço privado fica em segundo plano para ser substituído por um escopo mais amplo de narrativas de pertencimento. Resíduos desse anseio por um lugar de permanência perpassam diversas práticas sociais, como nos mostra Leontis. Nas diferentes formações dessa busca pela origem, há um desejo de estabilidade afetiva que neutralize a incerteza sobre qual lugar cada indivíduo pode reivindicar. Para isso, empreende-se um esforço narrativo que legitime, explique e crie redes causais para representar o lugar de pertencimento. Nesses contextos, essas tessituras funcionam metaforicamente como a casa que o indivíduo deseja controlar e que lhe serve de orientação para se movimentar nas coordenadas sociais. Bozkurt (2009: 28) argumenta que esse desejo de reconstrução de macronarrativas pessoais está atrelado também a um desejo de retorno à infância - a um período da vida, portanto, que muitos vivenciam como uma fase marcada por uma intensa sensação de proteção e pelo arraigamento afetivo.

Um terceiro círculo que define a casa como metáfora existencial - além do espaço primário de proteção e orientações e das macronarrativas culturais que definem pertencimentos - é o vetor do sentido existencial. Enquanto as macronarrativas culturais tendem a perseguir o desejo de reconstrução de um lugar de origem a fim de reforçar a estabilidade do pertencimento, a narrativa teleológica se esforça em eliminar a contingência num plano existencial. Leontis (1999: 4) escreve:

No período moderno, a maioria das pessoas perdeu sua crença na ordem cósmica, que lhes atribuía um telos na vida terrena, e na ordem geográfica, que lhes dava um lugar designado na terra. Elas passaram a acreditar que o seu lugar na história e na geografia era antes acidental que imbuído de sentido. ${ }^{6}$

Diante do abandono das grandes narrativas teleológicas, o indivíduo passa a ser responsável pela construção não somente da casa como proteção contra as intempéries, mas também de uma casa, no sentido existencial, contra a sensação de contingência e vacuidade. Como na casa material, por vezes o indivíduo herda essas construções e as

\footnotetext{
${ }^{5}$ No original: "At the same time, we yearn restlessly for a place of rest. Popular culture offers personalized packages: family genealogies; pilgrimages to the monuments of immigration such as Ellis Island; books about ethnic traditions; tours of lost homelands; communities of subscribers sharing the same network, chat-line, or cause; a compendium of comforting quotes, even the philosophy of baseball, which defines the all-American game as one of wanting to reach home and learning how hard it is to get there".

${ }^{6}$ No original: "In the modern period, most people lost faith in a cosmic order that assigned them a telos in earthly life, and in a geographic order that gave them an appointed spot on earth. They came to believe that their place in history and geography was accidental rather than meaningful" (LEONTIS 1999: 4).
}

Pandaemonium, São Paulo, v. 23, n. 40, mai.-ago. 2020, p. 43-62 
Mathias, D. - A casa como imagem

mantém sem grandes alterações. Outras vezes, ele se vê sozinho diante da tarefa de montar a própria casa.

Em três poemas centrais da coletânea Post Bellum, Dragica Rajčić (2000) problematiza a casa como imagem e como metáfora. Por um lado, há uma captação de impressão imagética no estilo de um snapshot; ao mesmo tempo, contudo, a casa se revela como metáfora para algo mais complexo, condensando questões da guerra, da estrangeiridade, de gêneros, mas também de materialidade linguística. Isso se torna premente no contexto em que a coletânea se inscreve, isto é, no pós-guerra, um momento marcado não somente pela destruição substancial do espaço de proteção da casa, mas sobretudo de reconfiguração das narrativas sociais e do próprio sentido existencial. Um segundo aspecto que intensifica a discussão sobre a casa reside na reestruturação que acompanha o movimento do fluxo migratório. Nos três poemas a serem abordados na sequência, a voz lírica adota a perspectiva de uma refugiada na Suíça, o que produz um despertencimento duplo causado pelos tumultos da guerra e pelo desejo de localização num novo espaço cultural. Nesse sentido, este artigo se propõe a discutir a figuração da casa como grande metáfora nos poemas: "suisse like home", "Hunderste gedicht ohne trenen" e "Ein Haus, nirgends".

\section{Deslocamentos e confluências}

O primeiro poema a ser discutido apresenta um título com uma mescla de línguas: o país em francês e a comparação em inglês: "Suíça como em casa". Como um todo, o poema não se atém às práticas normativas do uso da língua, incluindo nisso desvios ortográficos, sintáticos e também no uso diverso, por exemplo, dos artigos. A voz lírica que fala nesse poema é uma voz não nativa que busca participar dessa comunidade linguística, modelando o material da língua a partir de sua experiência pessoal. O título do poema já revela essa preocupação quando procura, por meio da economia de palavras, captar uma interseção afetiva centrada na questão da casa como metáfora da existência. Na sequência, encontra-se o poema e sua tradução:

Pandaemonium, São Paulo, v. 23, n. 40, mai.-ago. 2020, p. 43-62 
suisse like home ${ }^{7}$

1 Suisse home

2 im haus gegenüber meinen

3 dunkelen fenster

4 ein mann hat bevor er nerven verloren hat

5 frau blau geschlagen

6 polizisten brachten mann

7 brachten frau

8 mit dem auto

9 fort.

10 spaeter war es ruhig

11 es geht mir

12 licht auf

13 wie zu hause.

(RAJČIĆ 2000: 45)

\section{suisse like home}

1 Suisse home

2 na casa em frente a minhas

3 janelas escuros

4 um homem antes de perder cabeça

5 bateu mulher [deixando-a] roxa

6 policiais levaram homem

7 levaram mulher

8 de carro

9 embora.

10 mais tarde tinha sossego.

11 desponta em mim

12 uma luz

13 como em casa.

Num primeiro momento, o título sugere uma possibilidade de pertencimento, pois a voz lírica parece experimentar uma configuração afetiva como aquela vivida no lugar da primeira socialização. Especialmente ao utilizar a palavra inglesa "home", são concretizadas conotações de uma atmosfera afetiva positiva, enfeixadas numa única palavra, atualizando a ideia de arraigamento existencial, mas também mantendo indícios de cosmopolitismo. Esse cosmopolitismo é reforçado pela utilização de três línguas diferentes no título (francês, inglês e alemão), remetendo indiretamente ao

\footnotetext{
${ }^{7}$ Todas as traduções são do autor deste artigo.

Pandaemonium, São Paulo, v. 23, n. 40, mai.-ago. 2020, p. 43-62
} 
Mathias, D. - A casa como imagem

multilinguismo do país e intensificando a ideia do potencial de pertencimento a partir da diversidade cultural.

De certo modo, a voz lírica sugere que está em casa nesse contexto babilônico (AMODEO 1996), embora a sensação de pertencer àquele lugar permaneça ambígua. Essa ambiguidade se concretiza ao problematizar a crise do pertencimento nos poemas, por um lado, e ao indicar seu desejo de arraigamento quando utiliza a língua e contribui para a criação artística daquele lugar, por outro. Ao mesmo tempo que permanece a dúvida da crise, há uma espécie de confiança em poder estabelecer uma voz própria e até reimaginar aquele espaço de interação. A paronímia ${ }^{8}$ entre "Suisse home" e "sweet home" (doce lar) intensifica essa ambiguidade, pois contém traços de afirmação, mas também de ironia.

O primeiro verso retoma os lexemas "Suisse home" do título, excluindo, contudo, o nexo de comparação. No lugar da comparação, segue uma espécie de redefinição que busca compreender a imagem da casa nesse novo espaço cultural. Esse movimento começa com a utilização contrastiva das palavras "home", em inglês, e "haus", em alemão. Enquanto a primeira contém, em seu escopo semântico, um teor afetivo substancial, a palavra alemã, embora não neutralize completamente essa dimensão, atualiza, sobretudo, o aspecto da construção. Em ambos os casos, trata-se de imagens do espaço da casa. Os versos dois e três reforçam a ideia da palavra alemã casa como construção, indicando a presença de uma voz desejosa de narrativa pessoal atrelada a esse espaço. Assim, as janelas escuras a partir das quais a voz lírica olha para a casa à sua frente remetem a uma justaposição de espaços construídos. O processo de atribuição de valor semântico começa com a inserção desses espaços numa narrativa pessoal.

A primeira estrofe ainda não indica o nexo que a voz lírica vai construir a fim de mostrar um elo de pertencimento. Ela se limita a captar complexos imagéticos percebidos a partir de seu ponto de vista. $\mathrm{Na}$ arquitetura do poema, os versos quatro a nove introduzem uma ruptura que desconstrói a ideia da casa como espaço afetivo positivo. No lugar da harmonia e da proteção, da ritualização do cotidiano e da densidade de sentido, a voz lírica se depara com violência, com um fenômeno, portanto, que o espaço da casa, em princípio, deseja excluir por meio dos muros de proteção.

Nessa sequência, que destoa abruptamente da imagem do título, a voz lírica se torna testemunha da violência doméstica. Nessa percepção, como em vários outros poemas dessa coletânea, há um movimento igualmente desconstrutivo das narrativas

\footnotetext{
${ }^{8}$ Agradeço aos pareceristas deste artigo por chamarem minha atenção para esse elemento.

Pandaemonium, São Paulo, v. 23, n. 40, mai.-ago. 2020, p. 43-62
} 
Mathias, D. - A casa como imagem

engessadas de gênero. A desestabilização da imagem reside na aparente banalização da violência. Ao ferir a mulher, o homem já perdeu o controle, utilizando-se da força para impor sua vontade. A banalização inerente à exposição dessa percepção parece indicar que a casa como espaço também é responsável pela produção de papéis de gênero, distribuídos conforme os potenciais para proteger e usar a força física. Os níveis de proteção que a casa pode oferecer para os diferentes gêneros, portanto, diferem substancialmente.

Os versos seis a dez, em sua natureza de snapshot e que ressoa a melancolia do poema "Trauer auf dem Wäschedraht im Januar", de Rolf Dieter Brinkmann, expõem a sequência dos acontecimentos. A polícia leva tanto o homem como a mulher, restituindo a paz na vizinhança. Desprovidos de comentários por parte da voz lírica, os versos simplesmente parecem captar um acontecimento do cotidiano, sem atribuir valor a seu conteúdo. O dialogismo da voz lírica, contudo, fica marcado a partir da dissonância entre o desejo de caracterizar um espaço de pertencimento e a completa fragilização do seu potencial de proteção diante da violência. Com isso, o idílio da casa suíça sofre uma atualização inesperada, forçando o leitor a construir o nexo semântico que liga esses dois complexos imagéticos destoantes e excludentes.

A última estrofe abandona a verbalização do snapshot, isto é, a captura momentânea de uma percepção, a fim de construir um elo de experiência com a realidade da voz lírica. Até aquele momento sua atenção estava centrada na captação das imagens atreladas ao espaço da casa suíça. A ruptura marcada pelo início da segunda estrofe indica também a ruptura no fluxo de pensamento dessa instância de mediação. A concatenação causal produzida por ela reside na constatação de que os acontecimentos testemunhados têm muita semelhança com experiências presenciadas no lugar de sua casa.

Nesse movimento, há um alto teor de ironia e ambivalência, pois não determina o lugar dessa casa, deixando a locução "zu hause" num limbo semântico. Assim, na arquitetura do poema, a palavra "casa" oscila semanticamente entre casa como espaço nacional (entre Suíça e o país de origem), casa como espaço construído (nesse caso, a visão da casa do vizinho vista a partir das janelas escuras) e, por fim, casa como lar, onde a voz lírica presencia a gênese afetiva de si a partir das negociações de gênero, neste caso acompanhadas de violência. O poema não fornece indícios para definir os elos de identificação com o conflito da violência. Eles podem remeter a experiências no país de origem ou a experiências vividas na casa, a partir da qual a voz lírica enxerga os

Pandaemonium, São Paulo, v. 23, n. 40, mai.-ago. 2020, p. 43-62 
Mathias, D. - A casa como imagem

acontecimentos. Isso reforçaria uma leitura voltada para a decodificação da casa como espaço nacional. Ao mesmo tempo, contudo, os versos finais parecem conter um novo vetor de identificação, não mais voltado para o espaço nacional, mas sim para o posicionamento ou pertencimento de gênero.

A configuração cromática do poema reforça o processo de percepção vivenciado pela voz que o enuncia. Assim, a escuridão do lugar a partir do qual essa instância percebe os acontecimentos passa à luz que surge no lugar da cognição, tecendo um elo que retoma o atributo do título, a saber, "como em casa". Nisso, a casa não é concebida como um lugar de pertencimento espacial, como o título sugere num primeiro momento. Trata-se muito mais de um pertencimento a uma experiência de dor compartilhada que transcende as fronteiras políticas. Desse modo, o poema desconstrói a imagem da casa como espaço nacional e espaço de proteção, para inserir a imagem de um espaço construído sobre a interseção de experiências de dor comuns. A luz que surge no horizonte da voz lírica provém do reconhecimento de que a casa também pode ser definida como um lugar da dor, independentemente de ser suíço ou estrangeiro.

\section{Casa como lugar da fala}

O segundo poema a ser discutido tem o título "Hunderste gedicht ohne trenen", escrito, como o primeiro, com um material linguístico que não nega a estrangeiridade. Enquanto "suisse like home" imagina a casa como lugar de experiência comum, este segundo volta seu olhar para as modalidades de participação do outro no contexto nacional. Como no primeiro poema, há uma clara preocupação por parte da voz lírica em identificar a fragilidade da dinâmica de pertencimento. Nisso, ela compartilha com Andreas Gryphius, cujo poema "Thränen des Vaterlandes / Anno 1636" parece ressoar no uso de imagens, a inquietação sobre a violência e a concretização do espaço existencial.

\section{Hunderste gedicht ohne trenen}

1 noch immer bin ich nicht richtig von hier

2 von hier richtig sehe ich

3 das ich von irgends komme

$4 \quad$ kein Buch nimmt sich meiner an

5 kein Brandanschlag verbrennt

6 uns alle

7 wir sind eine art schlimme

8 befruchtung

9 tauchen unter 


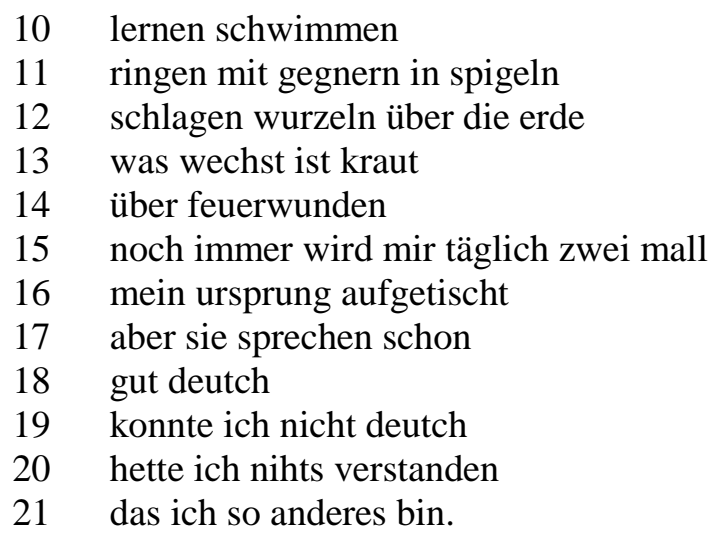

(RAJČIĆ 2000: 41)

\section{Centésima poema sem lagrimas}

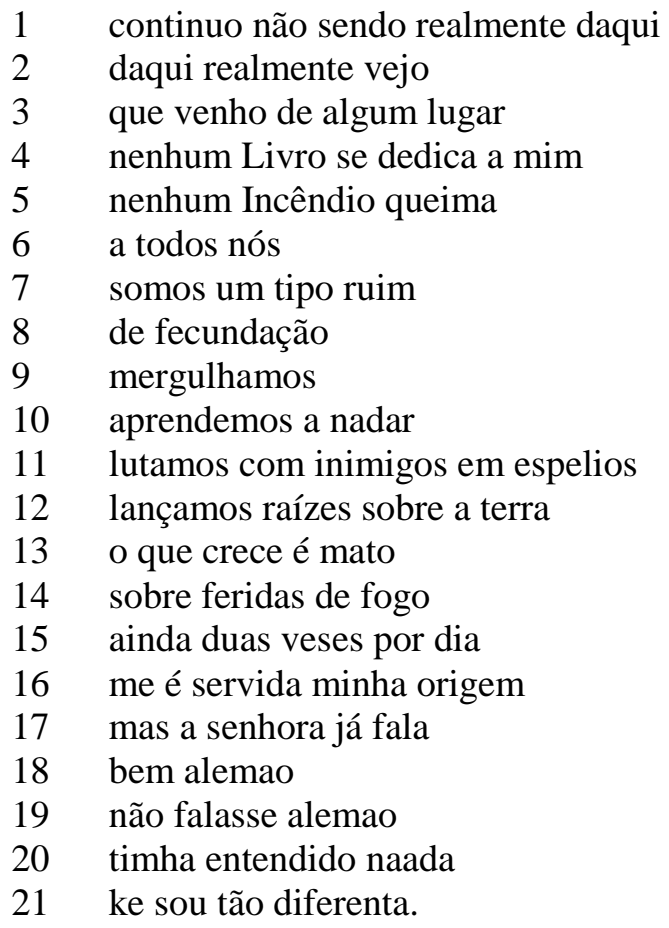

O título começa, antes de mais nada, com a afirmação da alteridade ao desviar da gramática normativa e declinar o adjetivo a partir do paradigma do gênero feminino, e não neutro, como prevê a norma. Ademais o numeral sugere inúmeras tentativas de processar alguma memória, atrelada com experiências de dor. A ausência de lágrimas parece remeter à intensidade do impacto dessa experiência sobre a narrativa de identidade dessa voz, ao mesmo tempo indicando uma disposição afetiva que aprendeu a dominar as incursões da dor, possivelmente a partir do trabalho de processamento, por meio da 
Mathias, D. - A casa como imagem

escrita. Com isso, a captação de imagens e sua concatenação na arquitetura do poema representam percursos de compreensão e processamento dessas experiências.

O verso que dá início a "Hunderste gedicht ohne trenen" explicita a origem dessa dor, a saber, na experiência de exclusão. Se no primeiro poema a imagem da casa surgia a partir da ideia de moradia, neste segundo ela se materializa a partir da casa como espaço das narrativas nacionais, isto é, a casa como nação. $O$ verso um ainda não explicita se o movimento de exclusão se origina de um comportamento do grupo majoritário ou se provém da sensação de deslocamento da própria voz lírica. Nesse momento, ainda permanece a ambiguidade, com cuja tensão o leitor se vê confrontado.

$\mathrm{Na}$ transição do verso um para o verso dois, retoma-se o adjunto adverbial de lugar, que ressurge invertido, enfatizando o lugar de fala. Repetida está também a palavra "richtig" (realmente, corretamente), como advérbio que define semanticamente "daqui", a qual etimologicamente também está atrelada à ideia de direção, de linha reta, como em "Richtung". No desenvolvimento da língua, o reto passou a assumir conotações de retidão, depois também de corretude. A imagem espacial primordial passa a ser utilizada para delimitar conteúdos morais e lógicos. Essa confluência de espaço com outras narrativas do mundo parece-me especialmente importante, pois a experiência da voz lírica na sequência do poema vai indicar algo semelhante, a saber, linhas demarcatórias (espaciais) e processos de inclusão ou exclusão, aqui, numa outra narrativa de mundo. Essas conotações que surgem a partir da recuperação etimológica da palavra certamente não estão na ponta do vetor semântico, na enunciação do poema, mas fazem parte do raio de sentidos potenciais que formam a densidade de todo o texto.

São justamente as linhas demarcatórias que começam a ganhar forma nos versos subsequentes. A tomada de consciência da diferença se dá no processo de deslocamento, a partir do novo lugar de fala. Os versos dois e três indicam que a voz lírica não tinha refletido sobre essa origem, de cuja direção provém. Ao mesmo tempo, ela constata que há um imperativo de origem, isto é, parece não haver possibilidade de existência sem uma narrativa de proveniência. É justamente o novo espaço de interação que força a voz lírica a criar o vetor de origem. Ela, contudo, não se vê capaz de fornecer essa narrativa, indicando que deve haver um lugar, mas sendo incapaz de definir qual seja.

Os versos quatro a catorze problematizam essa narrativa, introduzindo a imagem do livro. Como contêineres das narrativas sociais que servem para processos de autorrepresentação, eles não contêm registros sobre o pertencimento da voz lírica. Com

Pandaemonium, São Paulo, v. 23, n. 40, mai.-ago. 2020, p. 43-62 
Mathias, D. - A casa como imagem

isso, a incerteza da proveniência está arraigada na ausência de uma prática sociocultural de representação ou imaginação de comunidades (ANDERSON 2009). Confrontada com outras formas de administrar a imaginação da comunidade, a voz lírica experimenta uma sensação de desnorteio, diante da qual constata que deve haver uma origem; mas ao buscá-la nas macronarrativas sedimentadas nos livros, se depara com o vazio. Esse vazio é reforçado pelo uso de maiúsculas exclusivamente nas palavras "livro" e "incêndio". O silenciamento e o esquecimento são duplos, pois o incêndio da guerra tenta destruir e aniquilar a voz como produto do corpo, enquanto os livros não empreendem o esforço de recuperar os sedimentos da dor legados pelas narrativas do passado. As duas maiúsculas desse poema representam duas formas de silenciamento que marcam a experiência da voz lírica.

Diante dessa experiência maiúscula de silenciamento, o poema representa uma tentativa de instaurar uma voz própria. Nisso, o poema não se limita somente a um posicionamento diante das práticas discursivas, mas também apresenta uma materialidade linguística que recupera um lugar de fala próprio. Uma estratégia que a autora adota para representar essa busca reside no desvio ortográfico e da gramática normativa como forma de semantização. Exemplos disso são: "trenen - lagrimas” (Tränen - lágrimas), "spigeln - espelios" (Spiegeln-espelhos), “wechst-crece” (wächst-cresce), “mall-veses” (mal - vezes), "deutch - alemao" (deutsch - alemão), "hette - timha” (hätte - tinha), "nihts naada" (nichts - nada), "das - ke" (dass - que) e "anderes - diferenta" (anders diferente). Em grande parte, o desvio ortográfico mantém a proximidade fonética da palavra original, permitindo ao leitor afeito à gramática normativa identificar a palavra, sem dificuldade. Ao fazer isso, a autora busca representar a materialidade de uma língua própria, isto é, o "idioleto" dessa voz estrangeira.

Enquanto o verso quatro ainda utiliza o pronome possessivo da primeira pessoa do singular, os versos seis a treze utilizam marcas da primeira pessoa do plural. Com isso, houve um deslocamento da definição do si no nível pessoal para a definição do si no eixo étnico ou de pertencimento a um grupo. Essa definição passa pela imagem do incêndio. Dentro da rede cotextual que caracteriza a coletânea Post Bellum, há ao menos duas formas de contextualizar essa imagem. A primeira reside no segundo elemento do título, isto é, os incêndios como metonímia para as convulsões bélicas nos Bálcãs. A segunda concretização está atrelada à primeira parte, isto é, à experiência no pós-guerra, o que para a voz lírica significa a permanência no mundo germanófono. Não há necessidade de

Pandaemonium, São Paulo, v. 23, n. 40, mai.-ago. 2020, p. 43-62 
Mathias, D. - A casa como imagem

recuperação de informações biográficas para essa concretização, pois esse e outros poemas da coletânea permitem essa leitura. Nessa segunda concretização, o incêndio pode remeter aos ataques a casas de estrangeiros na década de 1990 (por exemplo, Mölln em 1992, Solingen em 1993), que fizeram manchete nesse período e estão presentes na memória coletiva, ao menos, de grupos minoritários.

Juntamente com a imagem da incerteza, os versos seguintes introduzem complexos imagéticos que remetem a experiências de adversidade. No lugar de uma narrativa coerente, passível de ser utilizada para fins de representação macrossocial, a voz lírica justapõe experiências de indivíduos marcados por uma luta existencial ininterrupta. Esta se caracteriza pela necessidade de aprender em meio ao perigo (mergulhar, e então aprender a nadar), de processar experiências traumáticas em forma de imagens do espelho, de fixar-se em áreas assoladas pela destruição a fim de fixar residência ("sobre feridas de fogo"). A palavra "kraut" (mato) se junta a essa sequência imagética que serve para caracterizar o grupo e reforçar a ideia do desejo pela vida, com sua afirmação existencial apesar de todas as adversidades. As conotações negativas desse substantivo, contudo, destoam das práticas de representação de grupo, geralmente esforçadas em recuperar os primores étnicos, como foi o caso, por exemplo, do imperativo estético das literaturas nacionais ao longo do século XIX. No poema, a palavra atualiza conotações de desamor, de estigmatização, de marca negativa. No lugar do primor, a narrativa do grupo está marcada pelo princípio de um pertencimento estigmatizado.

Os versos 15 a 21 contêm a terceira e última parte do poema. A primeira parte aborda o desnorteamento experimentado pela voz lírica ao se encontrar inserida no novo contexto social. A segunda tenta recuperar uma narrativa de grupo que permita a autorrepresentação. A terceira parte, por fim, reconstrói o lugar de fala, com seus desafios de negociação. Nos três momentos, a imagem da casa permanece como anseio da busca empreendida pela voz lírica.

Nesse último passo, a casa se materializa como pertencimento a uma comunidade linguística. Embora a voz lírica se sinta pertencente a essa comunidade cultural - sua reação diante dos questionamentos implícitos de seus interlocutores sugere isso -, seu lugar na casa permanece incerto. Aqui, o critério utilizado pelo interlocutor para administrar o princípio de inclusão e exclusão está atrelado à materialidade fonética da língua, isto é, seu idioleto. Embora o movimento desse interlocutor possa ser considerado inclusivo - afinal de contas, ele elogia os conhecimentos da voz lírica -, também traça

Pandaemonium, São Paulo, v. 23, n. 40, mai.-ago. 2020, p. 43-62 
Mathias, D. - A casa como imagem

uma linha demarcatória. Aqui, a casa da nação é formada por aqueles que apresentam a incorporação de um conhecimento biofonético que permite reconhecê-los como nativos da língua.

Para a voz lírica, essa linha demarcatória enfatiza uma diferença que para ela parece ser secundária. O confronto diário com as marcas de exclusão de um espaço da vida, do qual se sente parte, produz a configuração afetiva indicada no título do poema. A melancolia que surge dessa experiência cotidiana reforça ainda mais a fragilidade do arraigamento nesse espaço. Essa disposição afetiva, contudo, não produz o silenciamento ou a aceitação das práticas de inclusão e exclusão. Pelo contrário, a enunciação do poema indica um movimento de resistência que busca reformular a narrativa da casa. No trabalho de imaginação, surge um espaço de pertencimento que vislumbra um lugar onde a casa também acolhe a diferença, marcada por sotaques e desvios da norma. Com isso, Dragica Rajčić se junta às vozes daqueles que buscam reimaginar a ideia de nação.

\section{A literatura como casa}

A imagem da literatura como casa não é nova. Para Rose Ausländer (2002), por exemplo, a língua representou um refúgio contra as convulsões políticas e a barbárie. Para Dragica Rajčić, por questões semelhantes, a literatura também representa um lugar com maiores potenciais de pertencimento e liberdade. Diante das atrocidades da guerra nos Bálcãs e diante dos questionamentos sobre o escopo de seu pertencimento como estrangeira no novo contexto cultural, a literatura parece oferecer uma casa para a narrativa do si e do mundo que circunda a voz lírica. Como Rose Ausländer (2002: 36) em seu poema "Wege" ("Caminhos"), o qual termina com o imperativo "Geh in den Steinbruch der Wörter" (“Adentre a pedreira das palavras"), Rajčić retrata a dinâmica da palavra a partir do movimento em seu poema "Ein Haus, nirgends":

\section{Ein Haus, nirgends}

1 wenn

2 stïck

3 für stück

4 glaube

5 von Wortern

6 herunter fehlt

7 was

8 mache ich dort

Pandaemonium, São Paulo, v. 23, n. 40, mai.-ago. 2020, p. 43-62 
9 was mache ich da

10 ich sammle Silben

11 baue Ihnen

12 ein haus, nirgends

(RAJČIĆ 2000: 127)

\section{Uma Casa, em lugar nenhum}

1 se

2 parte

3 por parte

4 a fé

5 das Palawras

6 cair/faltar

7 que

8 farei lá

9 que farei ali

10 eu junto Sílabas

11 construo para Elas

12 uma casa, em lugar nenhum

O poema "Uma casa, em lugar nenhum" sintetiza imagens sobre formas de afiliação às práticas da criação literária, mas também remete à ideia da casa como sentido existencial. O título do poema parece ressonar o conhecido texto de Christa Wolf, Kein Ort. Nirgends, que retrata o encontro fictício entre Heinrich von Kleist e Karoline von Günderrode - dois protagonistas da literatura de expressão alemã que buscam a literatura como casa para abrigar seu sentido existencial. Semelhantemente à obra de Wolf, também o poema de Rajčić contém no título um paradoxo que antecipa a aporia dessa busca ou, ao menos, a impossibilidade de estabilização.

O poema parece apresentar duas concepções da língua como casa. A transição ocorre a partir de uma experiência afetiva, a qual gera uma transformação na visão de mundo da voz lírica. Assim, na primeira parte do poema, quando a voz lírica indica que há uma alteração no modo como administra seu relacionamento com as palavras, a matéria prima de sua arte, ela utiliza a imagem "parte por parte" para indicar o caráter paulatino dessa transformação. Nisso, ela enxerga a palavra como um fenômeno constituído por elementos concretos, quase palpáveis. Essa ideia parece estar bem próxima de uma concepção estruturalista, em que todo significante tem um significado, composto por um número definível de semas. Tão logo um sema sofre um deslocamento, 
Mathias, D. - A casa como imagem

há também uma alteração de sentido. A casa, como metáfora para a arquitetura da palavra, é estável, concreta, localizável.

Essa concretude é reforçada pela palavra "fehlt", que deve ser traduzida como "faltar", mas em conjunto com "herunter" e numa poética da estrangeiridade pode ser atualizada também como "cair", na ortografia normativa "fällt". A diferença ortográfica ocorre por conta da alteração da pronúncia do "e". Na tradução optamos por deixar as duas palavras, pois ambas indicam uma presença que sofre um deslocamento. Para cair ou para faltar é necessário que haja uma presença quase física de algum elemento, o que de certo modo está figurado no plano da palavra, por conta do deslocamento da unidade mínima fonética /e:/ e /ع/, no caso da palavra "fehlt".

Essa concretude da palavra como casa do sentido também permitia a voz lírica nutrir sua fé no potencial construtivo inerente à sua constituição. Essa fé talvez possa ser entendida não somente como crença na capacidade da palavra de produzir referência, comunicação e instauração de realidade, mas também, num plano maior, de produzir malhas teleológicas que permitam à voz lírica tecer uma narrativa de identidade e de mundo, imbuída de finalidade e, mais concretamente, de sentido. Com o deslocamento do sentido e sua possível ausência, não é somente a matéria-prima da língua que perde sua finalidade: é sobretudo a voz lírica que identifica a vacuidade existencial de uma narrativa do si que está arraigada, antes de mais nada, numa espécie de metafísica da palavra.

A repetição dos questionamentos nos versos sete a nove, portanto, indica uma voz lírica diante de um desnorteamento causado justamente pela presença de um sentido, cuja desintegração a voz lírica vislumbra em seu horizonte. A repetição dos dêicticos reforça um desejo de estabilização e, sobretudo, de fixação que a experiência de contingência do sentido não oferece mais. As perguntas verbalizam a crise de um momento que a voz lírica percebe como necessidade de modificar sua própria narrativa de identidade e o modo como administra sua produção pessoal de sentido.

A última parte do poema, versos dez a doze, propõe uma alternativa. Esta se afasta da concepção inicial, pautada pela presença de um sentido palpável no cerne da palavra. $\mathrm{Na}$ verdade, o ponto de partida já não é a palavra, mas sim as sílabas. Como segmentos fonéticos da palavra, elas não contêm sentido de forma independente. No lugar de se aproximar da palavra com a expectativa de que esta simbolize uma referência importante à voz lírica, ela desmonta sua unidade a fim de alcançar um sentido pessoal.

Pandaemonium, São Paulo, v. 23, n. 40, mai.-ago. 2020, p. 43-62 
Mathias, D. - A casa como imagem

O trabalho com as sílabas e seu conteúdo fonético representa uma tentativa de construir uma nova casa que consiga abrigar os sentidos que a voz lírica deseja comunicar e utilizar para sua própria representação. Aqui os papéis da criação e do fazer literário se destacam como caminhos para a busca do pertencimento. Esse pertencimento, contudo, não está arraigado na língua padrão, mas sim na língua que surge a partir do processo criativo empreendido pela voz lírica, incluindo nisso a afirmação de sua estrangeiridade. Até aqui, o sentido parece se fixar no plano fonético de sílabas concatenadas e articuladas a partir das regras idiossincráticas do sujeito que as enuncia.

A indicação local, ao final do poema, contudo, desconstrói a ideia de fixidez e localização. Se até esse momento era possível imaginar que a presença do sentido residia na reconfiguração silábica empreendida pela voz lírica, sugerindo que a unicidade de concatenação de segmentos fonéticos poderia oferecer uma nova casa que abrigasse não somente o sentido da palavra, mas também o sentido existencial do sujeito, a parte final do verso rompe essa expectativa. O que surge é um paradoxo que se forma na concretude da imagem da casa, atrelada a uma localização inexistente.

Essa concepção final da casa está muito próxima do pensamento desconstrucionista da língua (ZIMA 1994), em que nenhum sentido se fixa, sendo diferido constantemente, num movimento de disseminação ininterrupta. Se antes ainda se atribuía à palavra o potencial de funcionar como casa do sentido, nessa virada final ela já não possui concretude para abarcar sentidos sólidos. No lugar da fixidez, surge a ideia de fluidez. Com isso, a casa deixa de ser um ponto específico identificável em coordenadas geográficas para se tornar um fluxo em constante movimento de redefinição. De certa forma, a casa passa a ser um rio no qual não se entra duas vezes, para recontextualizar a metáfora de Heráclito.

Essa concretização da palavra "nirgends" neste ato de leitura (ISER 1984) pode ser reforçada a partir dos contextos que acompanham o poema. A impossibilidade da fixidez da casa como sentido não é um fenômeno que se limita à semântica da palavra. Trata-se de uma experiência igualmente identificável no plano social, diante das convulsões da guerra, mas também no fenômeno do despertencimento no marco dos fluxos migratórios. Sem poder construir um lugar de solidez diante da insegurança da guerra, do despertencimento da condição de imigrante e diante da palavra com seus imperativos da morfologia normativa, resta à voz lírica o não lugar da constante redefinição.

Pandaemonium, São Paulo, v. 23, n. 40, mai.-ago. 2020, p. 43-62 


\section{Considerações finais}

Nos três poemas discutidos, a imagem da casa surge a partir de figurações bastante diversas. $\mathrm{O}$ primeiro deles ainda conjura essa imagem nos moldes espaciais concretos, em que o teto serve de proteção. Essa proteção, contudo, se revela tão frágil no novo contexto nacional da Suíça como no lugar de origem da voz lírica. Em ambas as situações, a casa como espaço de proteção não significa o mesmo para os diferentes gêneros. No segundo poema, a casa passa a ser figurada como espaço da comunidade e da nação, problematizando aqui os desafios de representação e de exclusão do grupo. O último poema, por fim, se detém na língua como casa e promessa de pertencimento. Nesse eixo, a voz lírica constata que o material linguístico disponível para sua arte não se mostra capaz de abrigar os sentidos aos quais atribui importância. Isso a força a recriar essa língua, sem, contudo, entendê-la como mecanismo capaz de conter e estabilizar o sentido.

Com isso, os três poemas remetem a um percurso no desenvolvimento da figuração da casa que parte do mais concreto e termina no mais abstrato. Enquanto a casa inicial ainda era localizável, com sombras e janelas, passando por uma casa da nação com negociações de inclusão e exclusão, a casa final é um não lugar, em que o sentido não se fixa. Fluida em sua essência, essa casa não deixa de ser casa, mas exige da voz lírica um trabalho ininterrupto de atualização e reformulação do sentido. Nos três poemas, há ecos de importantes vozes da literatura de expressão alemã, construindo com isso uma casa na literatura como forma de pertencimento.

\section{Referências bibliográficas}

AmodeO, I. ,Die Heimat heißt Babylon': zur Literatur ausländischer Autoren in der Bundesrepublik Deutschland. Opladen: Westdeutscher Verlag, 1996.

ANDERSON, B. Comunidades imaginadas: reflexões sobre a origem e a difusão do nacionalismo. Tradução: Denise Bottman. São Paulo: Companhia das Letras, 2009.

AUSLÄNDER, R. Regenwörter: Gedichte. Stuttgart: Reclam, 2002.

BOZKURT, E. Conceptualizing "home": the question of belonging among Turkish families in Germany. Frankfurt am Main: Campus Verlag, 2009.

Douglas, M. The idea of home: a kind of space. Social Research, Baltimore, v. 58, n. 1, 1991, p. 287-307.

HINCK, W. Stationen der deutschen Lyrik: Von Luther bis in die Gegenwart: 100 Gedichte mit Interpretationen. Göttingen: Vandenhoeck und Ruprecht, 2000.

ISER, W. Der Akt des Lesens: Theorie ästhetischer Wirkung. München: Wilhelm Fink, 1984.

LEONTIS, A. Primordial home, elusive home. Thesis Eleven, Thousand Oaks, v. 59, n. 1, 1999, p. 1-16.

Pandaemonium, São Paulo, v. 23, n. 40, mai.-ago. 2020, p. 43-62 
Mathias, D. - A casa como imagem

MatT, B. Der Aufbruch der Frauen (1970-2000). In: Rusterholz, P.; SOlBACH, A. (ed.). Schweizer Literaturgeschichte. Stuttgart e Weimar: Verlag J. B. Metzler, 2007, p. 400425.

PROBUL, A. Immigrantenliteratur im deutschsprachigen Raum: ein kurzer Überblick. Frankfurt am Main: R. G. Fischer, 1997.

RAJČIĆ, D. Post Bellum. Zürich: Edition 8, 2000.

ZIMA, P. Die Dekonstruktion. Tübingen e Basel: Francke, 1994.

Recebido em 2 de setembro de 2019

Aceito em 4 de janeiro de 2020 